Revue Interventions économiques

Papers in Political Economy

$51 \mid 2014$

L'économie politique du "care". Entre continuité et changement

\title{
The Homeless and Public Space: Urban Policy and Exclusion in Bologna
}

Les personnes en situation d'itinérance et l'espace public : politique urbaine et exclusion à Bologne

Maurizio Bergamaschi, Marco Castrignanò and Pia De Rubertis

(2) OpenEdition

Journals

Electronic version

URL: http://journals.openedition.org/interventionseconomiques/2441

DOI: 10.4000/interventionseconomiques.2441

ISBN: $1710-7377$

ISSN: $1710-7377$

Publisher

Association d'Économie Politique

Electronic reference

Maurizio Bergamaschi, Marco Castrignanò and Pia De Rubertis, «The Homeless and Public Space: Urban Policy and Exclusion in Bologna », Revue Interventions économiques [Online], 51 | 2014, Online since 01 November 2014, connection on 10 December 2020. URL : http://journals.openedition.org/ interventionseconomiques/2441 ; DOI : https://doi.org/10.4000/interventionseconomiques.2441

This text was automatically generated on 10 December 2020.

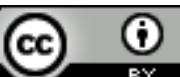

Les contenus de la revue Interventions économiques sont mis à disposition selon les termes de la Licence Creative Commons Attribution 4.0 International. 


\title{
The Homeless and Public Space: Urban Policy and Exclusion in Bologna
}

\author{
Les personnes en situation d'itinérance et l'espace public : politique urbaine et \\ exclusion à Bologne
}

Maurizio Bergamaschi, Marco Castrignanò and Pia De Rubertis

\section{Introduction}

1 Academic studies (Mitchell 2001, 2003; Mitchell, Staeheli 2006; Busch-Geertsema 2006; Cabrera 2006; Győri 2006; Meert et al. 2006; Sahlin 2006; Doherty et al. 2008) reveal the emergence, in recent years, of a common trend in Western cities, albeit with relevant differences between American and European contexts (Wacquant 2001; Tosi 2007; Huey 2009): the increasing control of urban public space which leads to a spatial exclusion and to a restricted "right to the city" (Lefebvre 1970) of homeless people. From zero tolerance policing to anti-social conduct by-laws, from privatization to militarization, from gentrification to sanitization, from pervasive surveillance to exclusionary urban design, each can be considered as an example of this trend. Yet, while living conditions of the homeless have been fully studied in European sociological literature and research, only a few contributions focus on the more specific relationship between homeless people and public space in the European "reassuring city", freed from fear, anxiety and nuisance. Instead, analysing this relationship and the urban politics related to it becomes a central and urgent issue in the current context of the progressive control of urban public spaces (Low, Smith 2006).

2 In this paper we discuss such relationship, focusing on the exclusivist trends in the Italian reality and particularly in the city of Bologna. The purpose is to examine some of the strategies aimed at excluding, regulating or punishing the behaviour of the homeless. Specifically, we concentrate on some of the latest politics of control and regulation of 
public spaces which, in order to protect quality of life, decorum, security and commerce, tend to control or exclude spatially the homeless from the spaces in which they live ${ }^{1}$.

In the following, we focus on three issues. First, we analyse how public spaces in the city are used by the homeless. In particular, we describe the relationship between public space and the homeless concentrating on the way in which the former is transformed into a "home" by the latter.

Secondly, we examine the transformations of public space, referring to processes such as gentrification, privatization and fortification. Specifically, we concentrate on the changes that city centres are undergoing in the processes of urban renewal focused on creating a new and desirable image of the city as a whole.

Finally, we explore the regulation of public space with reference to various urban public policies adopted in Bologna, in particular those by-laws dealing with decorum and security and urban furniture design, all aimed, more or less implicitly, at barring the visible homeless, the poor and other marginalized social groups from the gentrified city centres where their presence and their "irregular" use of public space could compromise city improvement. The ongoing spatial exclusion of the homeless is demonstrated both by using photographs showing those elements of urban furniture of exclusion which are appearing in many Italian city centres, and in Bologna in particular, and by a review of ordinances which, at a local level, are concerned with urban security and decorum.

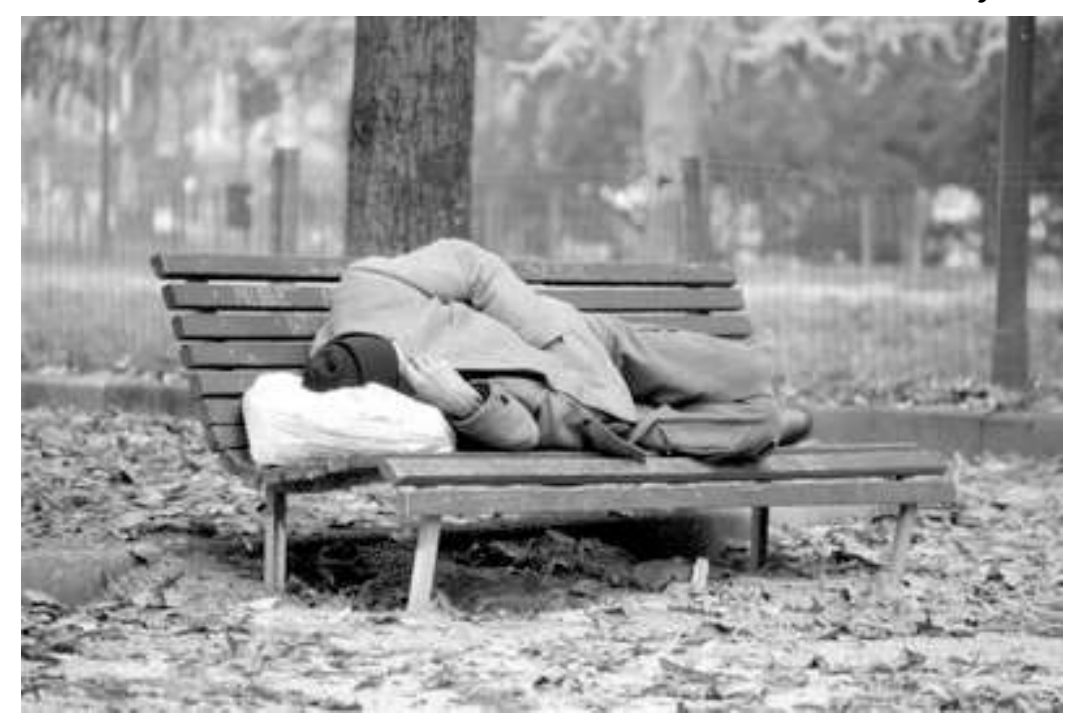

\section{Public space: a "home" for the homeless}

Public space is essential in the daily life of the homeless. Waldron (1991) usefully underlines that the traditional complementarity between the use of private space and the use of public space, which works correctly for the domiciled, fails completely in the case of homeless people. In other words, homeless people do not only live public space like the rest of the "public", rather they live in public space, having, by definition, no private space- homes- and no alternative but to be and live their lives in public. Hence, public space becomes a home, a place where homeless people tend to settle, more or less temporarily. It is a place where everyday life can be managed and a place where survival resources can be found. Private and public life cannot be separated: both are located in the public space. 
7 Walking through the streets of Bologna's city centre it is quite common to see marginalized people sitting or resting under the arcades, begging or wandering in general. In particular, in the course of our research into the use of inner city spaces we have discovered a whole world belonging to homeless people with its own spaces, rhythms, times, relationships and survival strategies. The inner city can be considered, in fact, as an ideal example of what Duneier calls "sustaining habitat" (Duneier, 1999, 144-153). Settling in the city centre shows us that homeless people rationally choose spaces that can help them to survive. Living on the streets forces the homeless to make choices continuously, as anyone would do in their daily life. However, it is not something done in a casual way; we can discern a strong rationality in the process, and such rationality is based on the reality of the individual's situation. The reality of living on the street defines the choices of the homeless person and affects every moment of his day and his entire life. We could say that urban public space "forces" the homeless to adopt particular behaviours. Furthermore, once a person is reduced to living on the street, the "traditional" supports of his life gradually become weaker and weaker, and ultimately tend to disappear. As a consequence, these people are deprived of their former identity; their life on the street shapes a new one. Hence, urban public space is not only the place where they spend most of their day, but it is also a mechanism which contributes towards shaping a new identity.

8 The main destination during the daily life of homeless people who live in Bologna is the inner city. Let us consider, for example, two of the most important survival strategies of the homeless: sleeping and money making. In the first place, Bologna's inner city architectural structure, famous for its arcades, offers an ideal solution for those who live on the streets and are looking for a safe place to sleep and "feel at home". The arcades and the corners of the narrow streets are attractive because they can be easily transformed into temporary beds, assuring not only protection from bad weather but also a certain sense of privacy. Furthermore, some homeless people also tend to occupy a specific space, marking the territory with visible signs, in particular piles of broken-down boxes. The possibility of creating this sort of stability, though, depends on the attitudes and tolerance of the residents of the areas where those spaces are created. Generally, settling in a particular place, "occupying" it or the appropriation of it will always be something temporary. The only way to settle permanently is to find a way of becoming invisible. The homeless tend, for the most part, to clean up their temporary private spaces before other citizens pass by. In the second place, the high fruition of Bologna's central area also guarantees the possibility of collecting money. Homeless people dedicate their time to a whole range of activities, like begging, cleaning the streets or selling newspapers.

9 The city centre, due to the high fruition of the area, fills a catalytic role, facilitating not only the possibility of looking for and of finding necessary survival resources (food, money, "ecological niches"), but also assures anonymity and a low social control (Castrignanò 2004, 81-82). On the basis of such peculiarities it is possible to talk, in the case of Bologna, of a new "man-territory relationship" and "structural coupling": the presence of homeless people is not only observable in the outskirts of the city or in degraded neighbourhoods, rather it becomes a phenomenon which tends to concentrate in the inner areas of the city.

10 The homeless who settle in public space by definition change the urban landscape; such space is the result of a negotiation between social actors, and the homeless "invade" 
public space and become stakeholders in it. Another example of "sustaining habitat" is the area of the central railway station of many cities in Italy. For the homeless a railway station is not necessarily a place connected to transport; rather, it is a place where they spend their everyday life, using services such as waiting rooms. To a certain degree, railway stations can even be considered their private space. In order to survive the homeless make use of all the resources that public urban space has to offer. The railway station is a place where they are able to wash, find shelter and sleep in relative safety. Other important spaces in the daily life of the homeless are church entrances where they can ask for money, fruit and vegetable markets or nearby garbage cans where they might find something to eat, betting shops or bars where they can warm themselves up for a while against the cold. So what the homeless do in public urban space is build up a survival circuit, a "constellation" of spatial and temporal points which are located in different parts of the city (Bergamaschi 1999).

Living on the street demands a very good understanding of the "underbelly of the city": otherwise the homeless would not manage to survive there very long. In other words, public space is the only place open to the homeless for finding the resources they need for living: what we see is a modification of the urban space, which the homeless adjust for their own needs.

In so doing they exert a form of control over it; public space becomes their place for making contacts and for interacting. This is an important point: the homeless are always considered people who are not able to implement any strategy, but they really do so in this case. We can say that the homeless are constantly developing tactics, strategies and means of mediation in order to survive and secure territory.

13 A homeless person's day is apparently empty, but in reality it is full of movement and challenge: there are many places in the city which are connected to basic needs such as sleeping, eating and all forms of human interaction. The living condition of the homeless forces them constantly to look for resources. Consequently some regular behaviours can be observed amongst the homeless: meeting other homeless people, finding something in the garbage, looking for money, looking for a place for the night and begging. So, the city provides several mechanisms that give a "rhythm" and sense to their lives.

However, if we consider the collective perception of the homeless, they are viewed as those "others" who don't respect the rules of public space and who cause disorder. They break the rules of dignity, privacy and social distance. Such conflict with the unwritten rules of public space creates a sense of disorder and uncertainty. In fact, conflicts in urban public space arise when unwritten codes of conduct, in particular rules of quality, security, decorum, civility, are broken by certain groups of people: teenagers drinking in a plaza, homeless sleeping on a bench, youngsters skateboarding. 


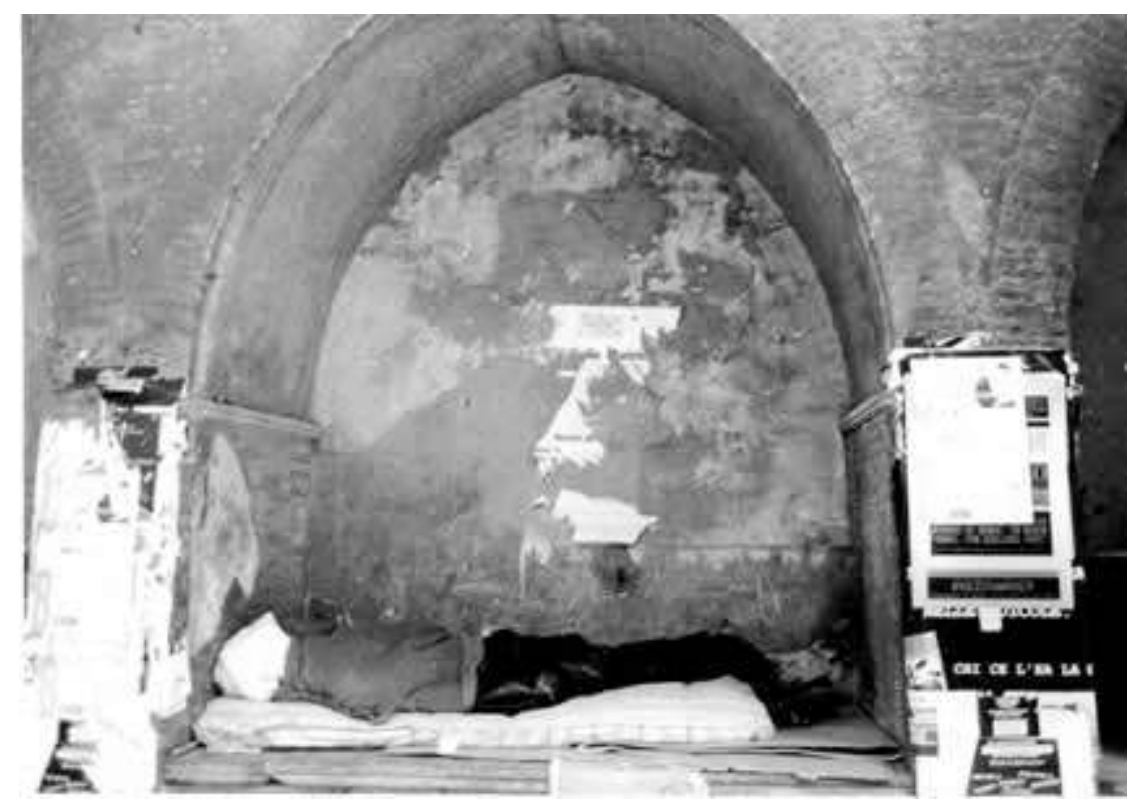

\section{The new image of the city centre}

Urban public space over the past two decades has experienced great change. Consider, for example, processes of fortification, such as the development of gated communities in suburban landscape, and privatization of public space, which detracts public urban ground from those with no buying power: shopping malls are the most obvious example but in Bologna's inner city even the chairs of many bars are increasingly invading squares, streets, arcades and parks. Or again, consider gentrification processes, pervasive surveillance and the presence of visible patrols in the streets, all of which are more and more frequent in Italian cities.

Among urban changes, the transformation of city centres is one of the most important with regard to the homeless, considering the significance of these areas in those people's daily life. In particular, "rediscovering the center" (Whyte 2009), based on a renewed interest regarding the potentialities of urban environment and, in particular, of the inner city in terms of profits, leads to considerable changes in central public spaces in terms of image, safety, design and policy. Such changes, in turn, mirror the apparently legitimate uses and users of public space.

The centre of the city, considered essential to a new neoliberal and entrepreneurial urban agenda (Harvey 1989), is subject to complex strategies of economic recovery. Such projects are aimed at conferring to the city a positive, innovative and desirable image which must be capable of facing the growing competition among cities, attracting new business, services and consumers. In this process, the city centre becomes a "shop window", a symbol of the identity of the city and is considered one of «the most characteristic places of post-modern architecture» (Strassoldo 1998, 59). Important characteristics become, amongst others, competitiveness, beauty, safety, usability. In particular, the control of public space is a fundamental strategy of neoliberalism (Low, Smith 2006,15$)$. In this sense, the entrepreneurial or neoliberal city is a strongly controlled and exclusionary one. 

centre is reevaluated and relaunched as a place of spectacle, consumption, fruition and animation (Mazzette, Sgroi 2007). Revitalization transforms public space into a space of fruition and consumption to which everyone is potentially able to access, but where new forms of inclusion/exclusion occur in the use of that space. In fact, such renewed spaces represents a battleground, where interests, life styles, values and norms of city users and residents clash with those of the homeless, for whom public space is inevitably their private space as well. Such improper use of public space nourishes conflicts with the rest of the public. In order to cope with these urban conflicts, more and more cities are adopting traditional and new control measures, to which homeless people necessarily have to adapt. If the homeless are able to react to the spatial and political limitations they encounter in their daily struggle to survive (Snow, Mulcahy 2001), indeed those measures influence their every day life, in terms of available spaces and actions.

Urban renewal strategies impose an ordered vision of public space, purified from the dangers of the "real" city (Amendola 1997, 182), and where, therefore, there is no place for marginalized groups whose presence could compromise the improvement of the city image (MacLeod 2002, 602). Such strategies, based on strong economic forces and on the current debate on unsafety, fear of others and disorder, transform the social and physical morphology of central public spaces and define who can use public space and how.

Urban renewal thus produces included and excluded citizens through the creation of public spaces which exclude certain social groups from their full access and use. Specifically, urban renewal projects borrow some of the typical features of suburban settlements and shopping malls (Aurigi, Graham 1997, 19-52). First, the relaunching of the inner city is influenced by the need for promotion and publicity. In particular, cities are planned as real "commercial goods". Second, the need for security and safety becomes central. Cities increasingly adopt several devices inspired by the "fortress" and the "panopticon" models: video cameras, walls, fences (consider the bars on the windows of ground floor flats), new devices of urban furniture to remove the unwanted (slopes, spikes, prickly plants, etc.). The primary necessity is, in fact, that of purifying, physically and socially, the urban landscape, in order to reassure ordinary citizens and commercialists.

21 If, on the one hand, urban renewal strategies certainly have positive aspects, as they respond to the negative consequences of sprawl, both environmental (as, for example, the massive use of the car) and social (isolation or less possibilities of face to face interactions) (Wassermain, Clair 2011, 75), and represent an occasion for kick-starting the economy of many cities, on the other hand, the same strategies entail paying a high price: the sharpening of socio-economic inequalities and the exclusion of certain marginalized groups (Macleod 2002, 602). The renaissance of the urban centre, in fact, leads to a sanitization of public space, both physical and social, removing anyone who does not conform to the promoted image: renewed spaces must be cleaned up from "broken windows" and "broken people" (Amster 2003, 207). Specifically, homeless people appear to be out of place. The city centre is modelled to respond to the interests of economic activities and of the well-being classes, at the expense of the weaker and disadvantaged, through the disciplining of urban space which includes a fusion of control architecture, exclusivist design and punitive policies, aimed at fostering partial views of who is considered part of the legitimate public and of how a public space should be used (Mitchell 1995). 

affected by the social groups who lived in that area. Such organization was a "mirror" of the social groups living there and the space assumed a symbolic connotation which gave sense to their everyday life (Sgroi, 1997; Castrignanò 2004). However, circumstances have changed. The inner area of this city has experienced and is experiencing great changes with the implementation of renewal projects focused on the relaunching of the city's image. With regard to the latest measures aimed at upgrading the city's image and improving the quality of its public space, we can recall, for example, the "BellaBo" program (2011), a series of operations for the relaunching of the city, which included the renewal of Piazza Giuseppe Verdi, a public square in the inner city which symbolizes the relationship between the city and its university. This square is famous for the diversity of its local user population (students, homeless people, immigrants, gutter punks, city users, shopkeepers) and holds a negative reputation, due to the concentration of a diverse range of incivilities carried out there. Again, consider the "Di Nuovo in Centro" program (2011) and the renewal of the three central squares: Piazza Aldrovandi, Piazza Malpighi and Piazza San Francesco (2014).

Bologna's inner city, hence, is now characterized by a high fruition. This not only makes homeless visibility become a problem, but also leads to a socio-spatial reorganization which has an effect on the social fabric, weakening it, which, paradoxically, is compatible with the need for anonymity and a low social control of the rootless urban poor.

However, it must be noted that Bologna is a city with distinctly particular characteristics. Physically, it is a city full of arcades, politically, its context is marked deeply by liberal ideologies, culturally, it is based on a welfare culture with a major openness towards the marginal groups and socially, where the existence of the oldest university in Europe means a massive number of students and a certain social organization. All of these particular features tend to contribute to the creation of less mean and hostile streets and a minor level of exclusion of homeless people from public spaces than in other cities.

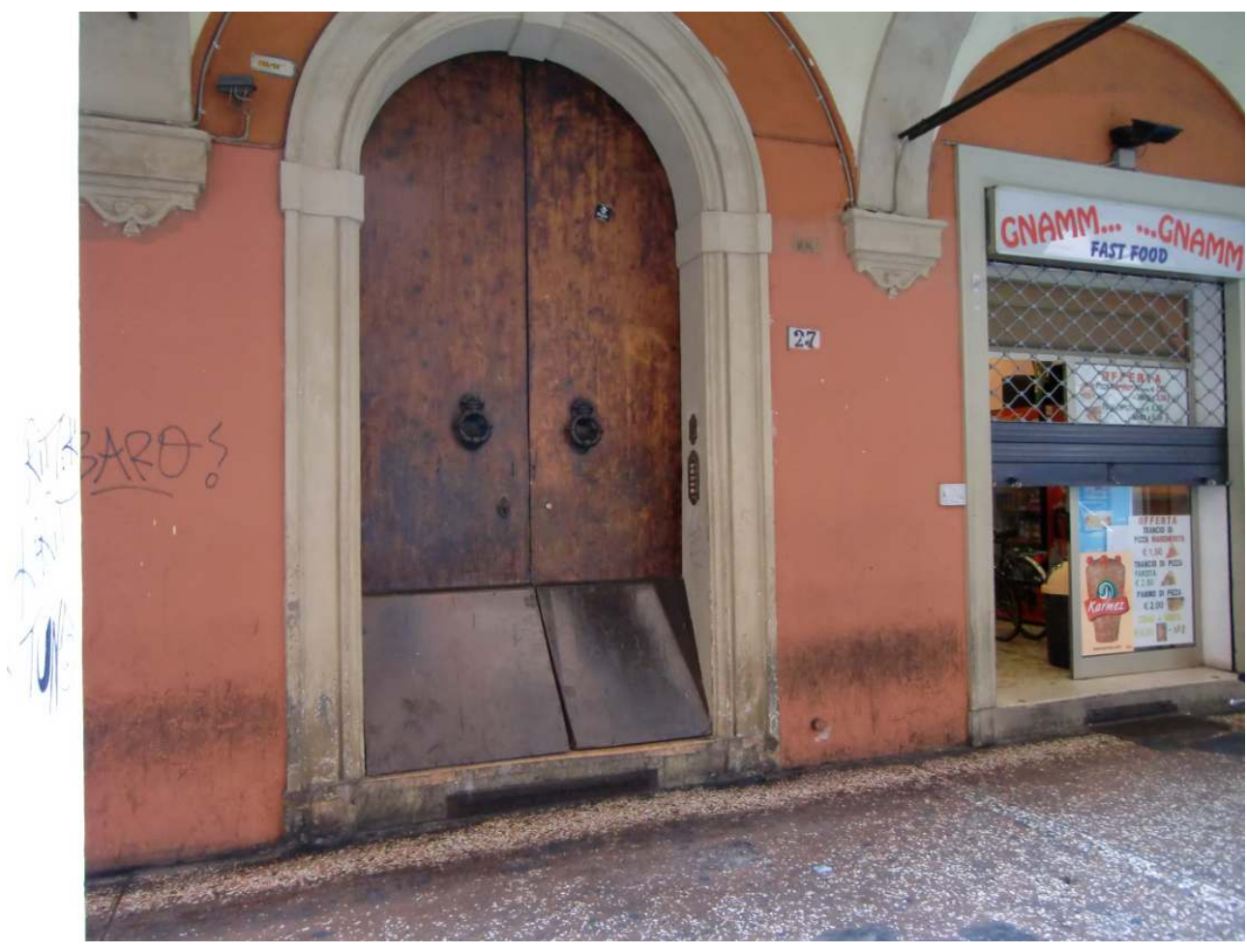




\section{The control of public space} of urban homeless (Mitchell 1995, 2001, 2003; Davis 1999; Wacquant 2001) does not apply equally to the trends of urban policing observed in European cities in general and Italian in particular, there are some important similarities. Referring to Italy, consider the following examples: the spread of panoptic shopping malls; types of gated communities, such as the Meridiana of Bologna (Mantovani 2005) and the Pineta di Arenzano district in Genoa (Porcu 2011); the pervasive surveillance under which every city in Italy is placed; the visible patrol officers, with both the public and the private sector providing security; spaces of mobility, such as railway stations, transformed under progressive privatization processes into shopping areas (in Bologna, Naples, Milan and many other cities); some examples of zero tolerance policies put forward recently by the Mayor of Salerno, Vincenzo De Luca, who ordered the Municipal Police to adopt zero tolerance against gypsies and homeless people (2013), or by Tosi in Verona, where offering a drink or something to eat to a homeless person could mean paying a fine of 25 to 500 euros (2014).

As far as the differences in exclusionary trends between the two contexts, American and European, are concerned, there are remarkable dissimilarities which have been well documented in the works of Wacquant (2001), Tosi (2007) and the European Federation of National Organisations working for the homeless (Feantsa) (Busch-Geertsema 2006; Cabrera 2006; Doherty et al. 2006; Győri 2006; Meert et al. 2006; Sahlin 2006). In short, European cities, due to their political, cultural and social background, seem to follow a European model of control and regulation of public space based on a less punitive and less pervasive approach than in American cities. Another important feature which marks the European reality is that the homeless are rarely the main and explicit target of these control measures; rather, in many European countries the most prominent target group are immigrants. Furthermore, we could say that, while in the USA there is an actual control of homeless people, Europe opts for a "reassurance policy" (Barker, Crawford, 2013, 11).

However, Tosi $(2007,226)$ rightly invites us not to underestimate the impact of such urban policy on who lives on the streets of European cities, due to a "coincidence of places" (city centres are both ideal spaces for the homeless seeking to survive and ideal spaces for commerce) and to the failure of the traditional complementarity between private and public space in the career of urban homeless people.

Fortification, surveillance, gentrification, privatization, sanitization and criminalization all contribute to the erosion of the socio-spatial justice (Mitchell 2003), as well as markedly redefining the nature of public space. Two relevant aspects at the basis of this new urban policy aimed at securing and sanitizing public spaces are the increasing sense of unsafety felt by citizens and the process of mercification which invests urban public space from the suburban territory (gated communities, shopping malls, etc.) to, more recently, the city centre (renewal processes). The former, only partially related to crime rates, is linked to, among other things, a whole range of sentiments of unease and to a distrust in the environment. Both unease and distrust derive from the decay of public space and from the deterioration of the quality of life, associated with incivilities and disorder generally attributed to the existence and visibility of "unwanted people and activities". Sleeping on the streets or benches, begging, drinking, washing in fountains or 
other forms of disturbing behaviour make public urban environment unpleasant, hostile and dangerous. As a consequence, the demand for security grows and leads to a real transformation of the city.

The need for safety and economic interests play a central role in the planning and government of urban landscape. Together, the two dimensions nourish and legitimize the formation of architectural and political measures to control public space, its use and its users.

Those in favour of control use stereotypes of disease and disorder to put forward justifications for such measures. Homeless people are labelled as being contagious, inferior, deserving of regulations which are presented as attempts to protect the wider public. In particular, starting from Miller's analysis, Amster (2003, 204-207) examines one by one the justifications at the basis of this new urban governance. Briefly: protection of public health and safety; economics; aesthetics; civility; crime prevention.

31 The current control strategies include, apart from the more traditional, direct and explicit tools (such as the use of legislation), new, implicit and almost invisible devices characterized by what Flusty (2001) means with the concept of "banality" since they pass mostly unobserved by ordinary citizens and tend to seem more acceptable.

In the following, we focus on two specific "deterrence" tools (Doherty et al. 2008) of this new urban policy, namely urban furniture of exclusion and local regulations on urban decorum and security. Such practices seem to determine the legitimate and appropriate users and uses of public spaces, or at least of those spaces that are characterized by a high fruition and oriented to consumption, where order, control, civility and decorum must be protected at all costs.

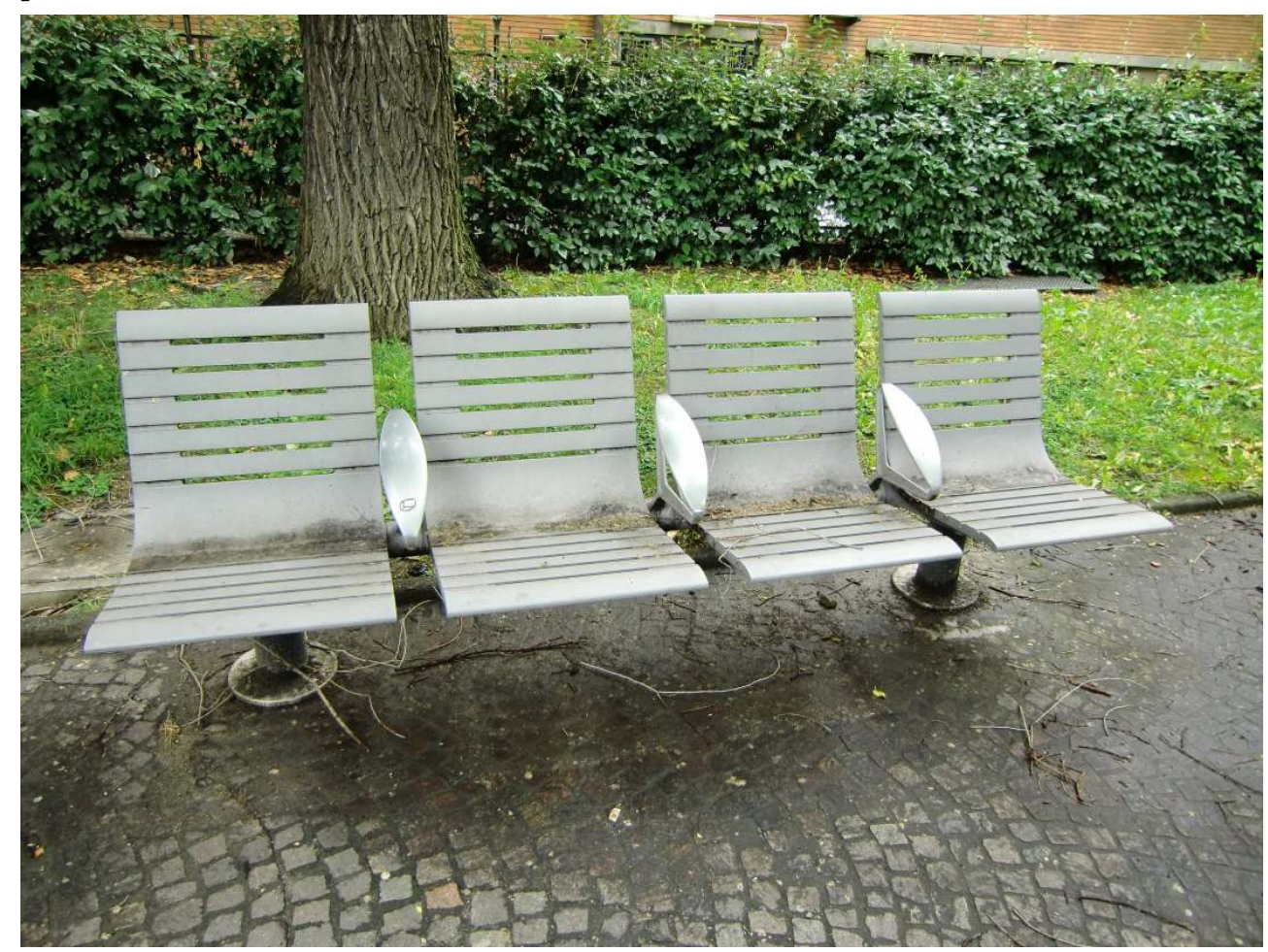




\section{Urban furniture as a tool to control public space}

33 In this section we discuss the adoption of material strategies, in the form of new urban furniture, being used by civic authorities to exclude the homeless from the use of public space. The term urban furniture includes the objects and the devices installed in urban landscape, thus in the streets and in the parks, for different purposes, such as benches, safety barriers, traffic divider culumns, postboxes, telephone boxes, lampposts, traffic lights, traffic signals, bus and tram stops, public toilets, fountains, garbage bins.

Mike Davis $(1999,232)$ was one of the first to talk about these strategies of exclusion of homeless people (consider "bum-proof" benches or outdoor sprinklers) in the Los Angeles urban landscape, where a "sadistic street environment" is emerging. More recently, the studies conducted by the Feantsa indicate the different ways in which urban furniture is used in Europe in order to control homeless life styles, for example "antihomeless" benches, gratings, fences, signs (Busch-Geertsema 2006; Cabrera 2006; Győri 2006; Meert et al. 2006; Sahlin 2006; Doherty et al. 2008). An interesting European project is the one carried out by the French artists collective called Survival Group (www.survivalgroup.org). This project, "Anti-sites", is focused on street and public area details that are created in order to avoid any kind of sitting, resting or sleeping possibilities. In particular, Arnaud Elfort e Guillame Schaller have made a photographic inventory of these kinds of hostile public spaces. The photos taken by the two French artists give a concrete form to the "interdictory space" concept introduced by Steven Flusty in Building Paranoia (1997).

A new type of urban furniture, clearly exclusivist and often imported, is making its way into Italian cities too, replacing traditional furniture in many streets and squares. The example of the so called "anti-homeless benches" is here emblematic. Traditional benches, the ones on which it was possible to sleep, seem to be a relic of the past. The new model which is appearing in Italian public spaces is divided by rails or bars which make it impossible to lie down, impeding its transformation into a temporary bed. Iron bars are also a way of ensuring isolation among people using the bench with no possibility of unwanted physical contact which generates a feeling of safety.

In Italy, in the last few years, local authorities have passed a considerable number of bylaws dealing with urban security. In one year, from September 2008 to September 2009, 788 local ordinances were implemented in 455 Italian municipalities (Cittalia Fondazione Anci Ricerche 2009), in order to fight the "illegal occupation of public space" and to ensure "decorum in the city" (Lorenzetto 2010). The introduction of law number 125 in 2008, extending the power of the Mayors to intervene with force in security matters, was the starting point from which these by-laws were able to be passed.

These by-laws deal, particularly, with the management of public space, in the form of prohibitions and rules of use. Typical urban situations to be attacked are degradation and disorder (drug traffic, begging, etc.), obstructions to public viability and decorum (for example, the illicit occupation of public space) and behaviour that can offend public decency.

An exemplary case of local policy against civil insecurities is the policy of benches. The redefinition of public benches becomes a sort of indicator of the battle over the lack of security and "civility". This battle against the improper use of benches assumes two 
forms; they are either removed altogether or they are carefully designed to impede unwanted uses.

Treviso was the first city in Italy to follow this "spatial war": already in 1997, Mayor Giancarlo Gentilini removed the benches from some central areas of the city with the aim of excluding immigrants. Similarly, in 2007 the Mayor of Trieste ordered the removal of benches from Piazza Venezia, but with the intent of ejecting the homeless. The Mayor of Padova continued the removal policy, eliminating in 2009 the public benches used in an improper way. In other cities, such as Belluno first, followed by Verona, Milan, Bologna and Savona, the solution has been found in the so called "anti-homeless benches", which do not welcome but exclude. In the course of time, other Italian cities, Rome and Naples, have moved in this direction. By-laws can not only define bench design but can apply to their use too. In Voghera the Mayor has prohibited sitting on public benches after eleven ò clock at night; in Vicenza, some public benches are reserved, with specific signs posting, for families, pregnant women and the elderly over 70; again, in Novara it is not possible to sit on a bench in groups composed of more than two people. Other ordinances present benches as public goods that must be protected from degradation, vandalism and dirtying. The Mayors of Gorizia and Monfalcone have forbidden the "improper use of a bench", the Mayor of Venezia has forbidden "sitting in a disorderly or improper way, like putting one's feet on the bench". Another operation is what Sebaste (2008) calls the "museification" of benches, that is the current fashion for embellishment and aestheticization of public benches.

The bench, in particular, is considered a suspicious place where homeless and immigrants can seek refuge. Hence, the bench, like the wider public space in which it appears, becomes a battlefield, a symbol of the struggle between two visions of living the city and its public spaces: on the one hand, a city lived as a place of transit and passage, on the other, a city as a place of exchange and interaction (Lorenzetto 2010, 6). Or again, on the one side, public space as a planned, controlled, orderly and safe space where a properly behaved public can experience the spectacle of the city, on the other, public space as a place of free interaction, where coercion by powerful institutions is absent and where risks of disorder and unpredictability are tolerated (Mitchell 1995, 115). Benches, conceived and designed on purpose as temporary supports, must be, like public space, places of decorum, order and predictability.

41 There are different types of anti-homeless benches. Some new benches are divided by armrests, that can be higher or lower and of different shapes (curved or straight), others have become single seats instead of the traditional benches. Urban furniture is now designed for temporary support only; there can be no sitting comfortably for a long time, reclining or stretching. In this respect, an important element emerges. Single seats do not only impede their use as sleeping places, they change the whole nature of a public bench from being a place of social exchange and relaxation to a space of brief and individual use (Lorenzetto 2010). In this sense, they not only tactically exclude the unwanted, they also deprive all town dwellers and tourists of the right to stroll and rest (Sebaste 2008).

In Italy, this is a recent phenomenon: the first anti-homeless bench appeared in Belluno in 2007 during Prade's administration. However, the intentions behind it are immediately evident. Pappalardo and Marazzini (2011) talking about the anti-homeless benches which appeared in Verona, write: «obviously the direct target of the new urban furniture are the homeless and the immigrants (...). In this regard, you can read that "the new benches will help to avoid contact between these drifters and kids and other users of the parks"». 
Homeless people and immigrants can be considered, in fact, the most frequent users of such urban furniture, both to rest and to store their belongings and, because these people are perceived as a nuisance to the ordinary citizen and a threat to urban decorum, they must be removed.

Anti-homeless benches, or whatever name is given to these new benches, "post-modern" (Flusty 2005), "hygienic" (Paté, Argillet 2005) or "bum-proof" (Davis 1999), clearly function as repellents or deterrents against unwelcome people. Through these benches cities control and regulate indirectly the use made of the same cities. It is a kind of disciplinary architecture, whose aim is to protect the general public from the unwanted behaviour of unwanted people (Lockton, www.architectures.danlockton.co.uk). Specifically, control is inserted within the object and forces individuals to conform to their legitimate use. In other words, in the case of the new benches: "sitting yes, lying down no".

The installation of this new urban furniture qualifies Italian public space as "anti-sites", as the two French artists, Elfort and Schaller, would say, or as "banal interdictory spaces", as Flusty puts it. A crucial aspect of this new urban design is that often it passes completely unnoticed by the ordinary citizen, the tourist or the suburban visitor who all gravitate to the spectacularized inner city. Most people with a home are not aware of these slight changes which, however, have a strong effect on the survival circuit built up by homeless people whose public space, which is their lifeworld and sustaining environment, is reduced.

Urban space is well-equipped to impede its improper use. The new inhospitable benches and anti-bivouac furniture are spreading throughout the urban landscape, in squares, parks, streets, as well as in railway stations and in metros. They are particularly found in public spaces characterized by a high fruition, and so frequented by a large number of residents and urban users and which usually coincide with central urban areas. The problem of homelessness is, in fact, a problem of visibility: what is important is that they are "out of sight" (Amster 2003, 196). Even railway stations, metros and bus stops are becoming more and more well-endowed to exclude unwanted people and behaviour. For example, consider the formal prohibitions introduced against resting in waiting rooms or charging money for using toilets.

Apart from the anti-homeless benches, there are several other tactics employed in the typology of urban furniture recently adopted by Bologna's City Council. Consider the "human spikes" (Williams, 2011), similar to those used for pigeons, which deter the unwanted from loitering in public. Or the closing-off with high railings or walls of places where the unwanted homeless often go to sleep.

The local Administration justifies such political strategies as a response to the increasing complaints and "demand for safety" from citizens, residents and shopkeepers, which derive from the improper occupation of public space. In short, the by-laws are aimed at reducing the sources of this unsafety. Hence, removing a bench or redesigning it means removing the poor, the homeless and immigrants, who are considered trespassers with no right to the city. But citizens themselves also adopt an active role in this process of transformation of public space. For example, in order to avoid somebody choosing the entrance door of their houses as a place to sit and rest, they install structures which impede even sitting only for a moment, such as metal sloping bars. Another example are the signs which ban bivouac: "No dwelling, sitting, etc.". 

people from using public space, especially those deemed to use it "uncivilly", is a city less and less accessible for the poorest people; as they cannot be eliminated or institutionalized, they are removed from places under the public eye, they become invisible, they are out of sight.

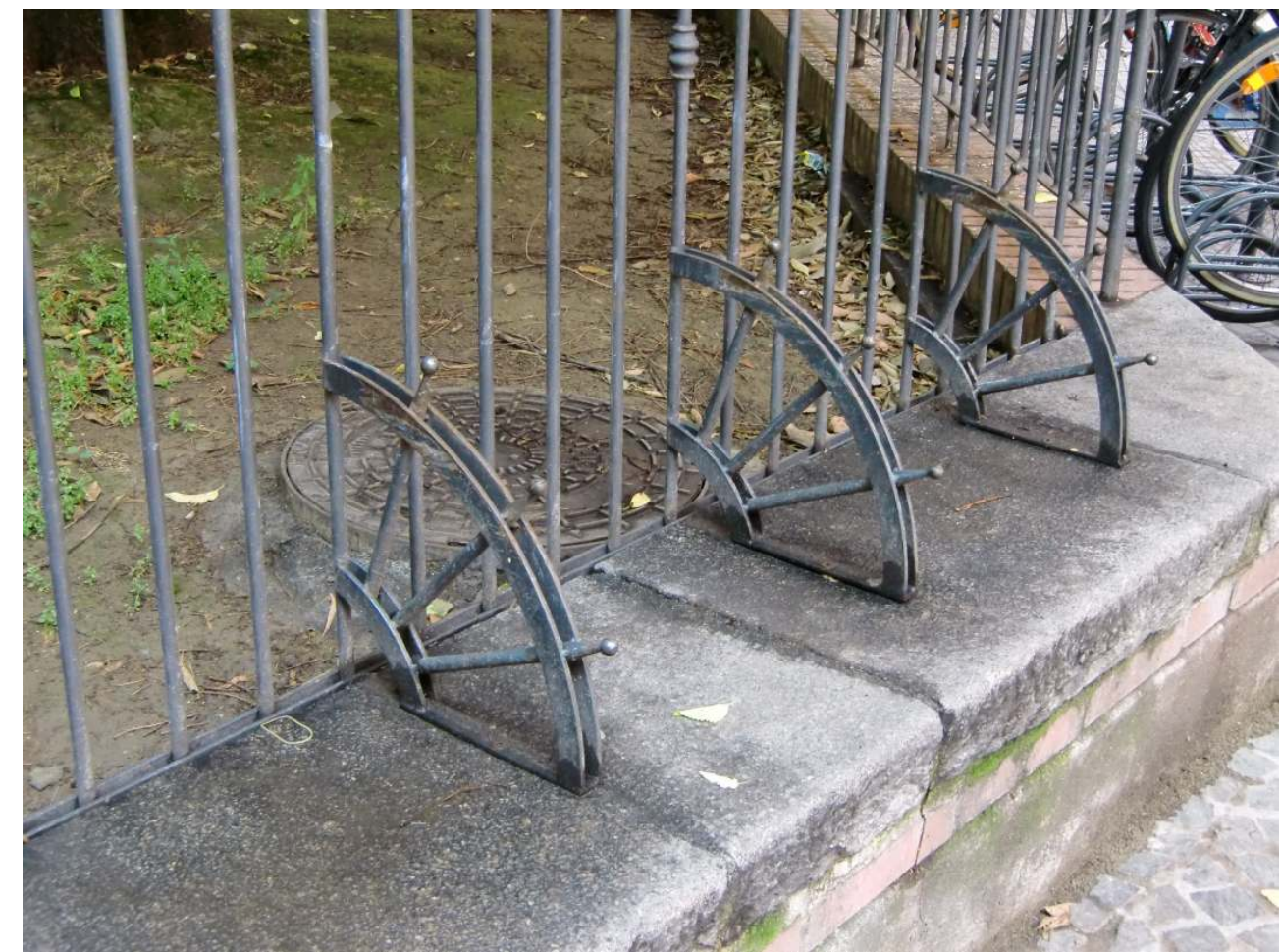

\section{Security and decorum by-laws}

Besides strategies of "deterrence through design" (Doherty et al. 2008, 301), legal regulation on the use of public space also applies. Strategies for controlling and regulating certain types of behaviour in public spaces, which outlaw activities such as drinking, sleeping on benches, begging, washing in fountains and so on, are growing in many Italian cities. The point of such restrictions seems to be the reduction of the annoyance from and the public visibility of those on the margins of society, and to permit all citizens, except the "unwanted", to use the public spaces of their city without disturbances. Order and decorum as defined by by-law mean regulating or forbidding 
behaviour clearly linked to the homeless. Activities like sleeping and urinating, which are perfectly legal if performed in private, are banned in public.

Thus, a more explicit deterrence tool, aimed at rendering public space safe, predictable and free from risks and of those who embody them, is the legal exclusion of the homeless through by-laws regulating public behaviour and the use and occupation of public space. Like urban furniture, local legislation is aimed at improving the quality of life, decorum, liveability and aesthetics of public space, in order to render it attractive for business and public normality.

, as in Europe, the legal exclusion from public spaces of unwanted people does not focus only on homeless, but also on other marginalized groups labelled as disturbing or even dangerous, such as gypsies and immigrants. If, on the one hand, only a few of the new security by-laws are directed specifically to the homeless, on the other hand, such people, due to their inevitable dependence on public space to survive, are the social group which suffers the most under these measures. So the homeless cannot survive without breaking the law and, as a consequence, society is scared of the weak and poor, instead of taking care of them.

In Bologna's urban policy agenda, as elsewhere in Italy, the issue of security, starting from the mid-'90s, has gained a central role. In this process, local Administration and its Mayor become "key-actors" (Giovannetti 2012, 12) in responding to the growing perception of unsafety of Italians. Within a few years several ordinances have been passed, which deal, in particular, with the management of urban public spaces in the form of prohibitions and rules of use. From the north to the south, several cities have adopted ordinances ranging from the prohibition of begging, considered disturbing and damaging to the free use of public space, a threat to decorum and tourism, an obstacle to viability or, again, a factor of unsafety, to the prohibition of bivouac and situations which cause urban degradation, including a whole range of bans (for example sleeping on the streets or rummaging in the rubbish).

In Bologna, the use of this kind of legislation occurs especially in a highly conflictual context, the central university area, in particular, Piazza Verdi and Petroni Street. One of the first attempts at responding to the presence of people considered a source of degradation, disorder and unsafety, namely the homeless and the gutter punks, was made by Mayor Vitali who in 1996 sanctioned bivouac in the university area. However, with the advent of the right wing party and the election of Giorgio Guazzaloca as Mayor in 1999, security became the main question in the government of Bologna's inner city. In the same year the new Mayor created a widespread system of surveillance and forbade the occupying of public spaces and behaviour contrary to public decency and decorum. In 2003 he also ordered restrictions on the consumption of alcohol, banned sitting on the ground and begging. In 2004, with the return of the left wing party and the election of Sergio Cofferati as Mayor, the struggle against urban degradation and disorder continued with the increase of visible patrols, the adoption of new by-laws and the demolition of some illegal encampments. From 2009 to 2010 Mayor Flavio Del Bono followed, even if for a short time, his predecessors. In 2011, with the election of the current Mayor, Virginio Merola, a further reinforcement of police presence has been established, together with further ordinances against degradation. Regulation of Urban Police, which has, for the first time, extended anti-bivouac 
legislation to the whole Municipal area, explicitly forbids, in article 12, bivouac, indecent, indecorous and out of place behaviour, such as sitting or lying under the arcades or in other public spaces, and behaviour which causes annoyance to citizens, including begging. On March $1^{\text {st }}, 2011$, the new Regulation came into force. Banned behaviour in public space includes satisfying physiological needs outwith places specifically designed for that, camping or dwelling in tents, vehicles, shacks or makeshift shelters, bathing in fountains and in public water or using it in an improper way, littering the streets. Other bans are on behaviour which causes annoyance or harassment to other citizens, the consumption of food and drinks in an improper way which impinges on decorum and begging which causes annoyance to pedestrians.

57 Other measures which join in the attempts to increase security and change the use of public spaces are the "Memorandum of Understandings in the Area of Urban Security" signed on September $20^{\text {th }}, 2005$, and, later, the "Agreement for a Safe Bologna", signed on February $17^{\text {th }}, 2012$. The aim of the latter is towards a general improvement in the degree of real and perceived security against urban disorder, in the framework of a renovated synergistic context between the Town Council and the Prefecture. This agreement envisages the renewal of urban spaces, the review of the existing system of surveillance and the strengthening of security forces in certain risky areas.

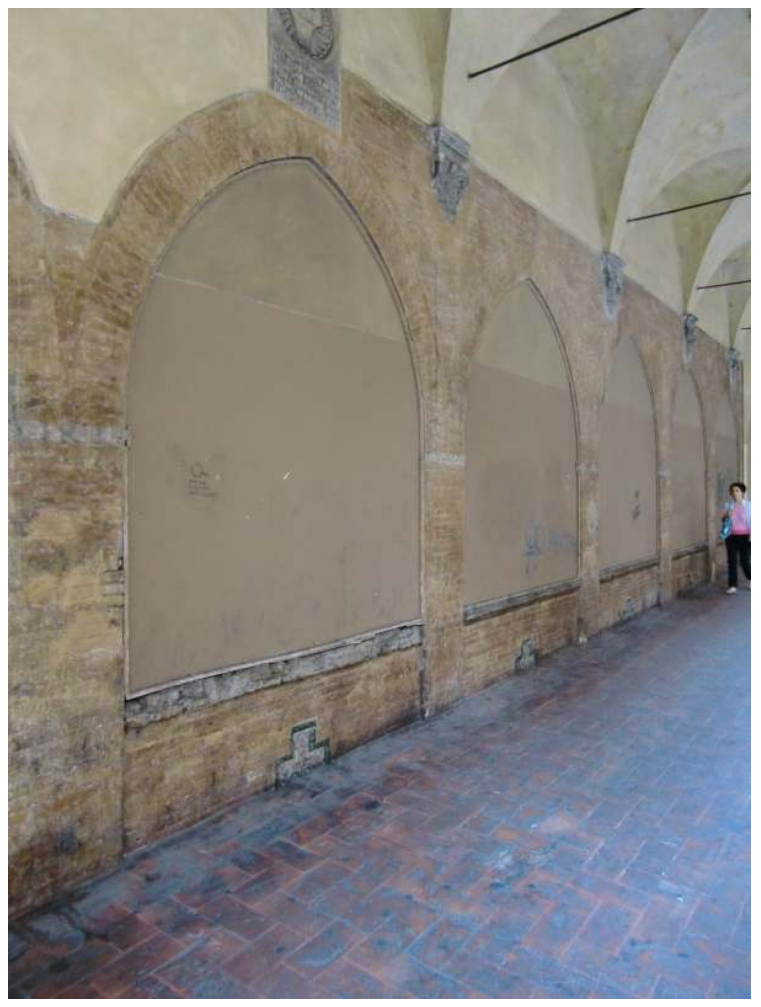

\section{Conclusions}

The urban politics analysed reflect the attempt at purifying certain public spaces from problematic and undesirable social groups, in the name of the wider public's quality of life and in the name of economic interests. One of the basic concerns of such political measures is the visibility of homeless people and their improper activities in the gentrified inner city which is now increasingly designed to be consumed as a real 
commercial good and to which a population which feels unsafe gravitates. The homeless are a nuisance because they are visible to the common citizen, to the consumer, to the elector; hence, they must be controlled. Specifically, the homeless person, using public space improperly and "unsettling" (Blomley 2004) the traditional distinction between public and private, visibility and privacy, becomes the enemy of the clean, ordered, decorous, safe and profitable city. So control policy is presented by its supporters and accepted by the ordinary citizens as right and necessary and concerns almost exclusively the city centre, where homeless tend to settle.

In conclusion, the attempt to maintain and improve the quality of public space is obviously desirable, but the problem is the collapse of public-private space complementarity in the lives of those who live on the streets. In fact, although not all the measures are directed to the homeless, many of these affect their daily life, translating automatically to a restricted right to the city.

Furthermore, this "low intensity warfare" (Davis 1999, 205) damages not only homeless people but also, although indirectly, all other citizens, fomenting a sense of fear and contributing to the creation of a falsified vision of the city, as well as redefining urban public space, which from our point of view is considered as a space of heterogeneity and celebration of differences. We must not forget what Wirth (1938) said in the 1930s: heterogeneity is one of the basic characteristics of the city.

\section{BIBLIOGRAPHY}

Amendola, G. (1997) La città postmoderna. Magie e paure della metropoli contemporanea. Bari: Laterza.

Amster, R. (2003) "Patterns of exclusion: sanitizing space, criminalizing homelessness." Social Justice 30 (1), 195-221.

Aurigi, A., and Graham, S. (1997) "Virtual cities, social polarisation and the crisis in urban public space." Journal of Urban Technology 4 (1), 19-52.

Barker, A., and Crawford, A. (2013) "Policing urban insecurities through visible patrols: managing public expectations in times of fiscal restraint.” In Lippert, R.K., and Walby, K. eds. Policing cities. Urban securization and regulation in a twenty-first century world. London: Routledge, 11-28.

Bergamaschi, M. (1999) Ambiente urbano e circuito della sopravvivenza. Milano: FrancoAngeli.

Blomley, N. (2004) Unsettling the city. Urban land and the politics of property. New York: Routledge.

Busch-Geertsema, V. (2006) Urban governance, homelessness and exclusion. Homelessness and access to space in Germany. National Report for Germany, Working Group 1, European Observatory on Homelessness, FEANTSA, Brussels. http://www.feantsa.org.

Cabrera, P.J. (2006) Conflict, homelessness and the use of public space in Spain. Working Group 2, European Observatory on Homelessness, FEANTSA, Brussels. http://www.feantsa.org. 
Castrignanò, M. (2004) La città degli individui. Tra crisi ed evoluzione del legame sociale. Milano: FrancoAngeli.

Chiodini, L. (2009) "Le ordinanze comunali a contrasto dell'insicurezza urbana: un'indagine nazionale." Autonomie locali e servizi sociali 3, 499-510.

Cittalia Fondazione Anci Ricerche (2009) Oltre le ordinanze. I sindaci e la sicurezza urbana. www.cittalia.it.

Davis, M. (1999) Città di quarzo. Indagando sul futuro a Los Angeles. Roma: ManifestoLibri.

Doherty, J., et al. (2006) The changing role of the state: homelessness and exclusion: regulating public space, Transnational Report, Working Group 1, European Observatory on Homelessness, FEANTSA, Brussels. http://www.feantsa.org.

Doherty, J., et al. (2008) "Homelessness and exclusion: regulating public space in European cities." Surveillance \& Society 5 (3), 290-314.

Duneier, M. (1999) Sidewalk. New York: Farrar, Staruss and Giroux.

Elfort, A., and Schaller, G. Anti-sites. www.survivalgroup.org.

Flusty, S. (1997) “Building paranoia”. In Ellin, N., ed. Architecture of fear. New York: Princeton Architectural Press, 47-59.

Flusty, S. (2001) "The banality of interdiction: surveillance, control and the displacement of diversity." International Journal of Urban and Regional research 25 (3), 658-664.

Flusty, S. (2005) Quoted in "Bench pressed. Steven Flusty gives Toronto's public spaces low marks.” YorkU Magazine. cpa.info.yorku.ca/yorku-magazine, 8.

Giovannetti, M. (2012) “Introduzione.” In Cittalia Fondazione Anci Ricerche ed. Per una città sicura. Dalle ordinanze agli strumenti di pianificazione e regolamentazione della convivenza cittadina. www.cittalia.it, 11-24.

Győri, P. (2006) Excluded groups in the city centre. How do different groups of homeless use public space in the large city? Working Group 2, European Observatory on Homelessness, FEANTSA, Brussels. http://www.feantsa.org.

Harvey, D. (1989) "From managerialsm to entrepreneurialsm: the transformation of urban governance in late capitalism." Geografiska Annaler 71B (1), 3-17.

Huey, L. (2009), "Homelessness and the "exclusive society". Thesis: why it is important to "think local" to "act local" on homelessness issues." European Journal of Homelessness 3, 261-273.

Lefebvre, H. (1970) Il diritto alla città. Padova: Marsilio Editori.

Lockton, D. Architectures of control in the built environment. www.architectures.danlockton.co.uk.

Lorenzetto, E. (2010) “Ordinare gli spazi. Rassicurare la città. Un'analisi sociosemiotica sulle politiche di sicurezza urbana." Rivista dell'Associazione Italiana Studi Semiotici online, www.ecaiss.it.

Low, S., and Smith, N. (2006) The politics of public space. New York: Routledge.

MacLeod, G. (2002) "From urban entrepreneurialism to a "revanchist city"? On the spatial injustices of Glasgow's Renaissance.” Antipode 34 (3), 602-624.

Mantovani, F. (2005) La città immateriale. Tra periurbano, città diffusa e sprawl: il caso Dreamville. Milano: FrancoAngeli. 
Mazzette, A., and Sgroi, E. (2007) La metropoli consumata. Antropologie, architetture, politiche, cittadinanze. Milano: Franco Angeli.

Meert, H., et al. (2006) The changing profiles of homeless people: conflict, rooflessness and the use of public space. Transnational Report, Working Group 2, European Observatory on Homelessness, FEANTSA, Brussels. http://www.feantsa.org.

Mitchell, D. (1995) “The end of public space? People's park, definitions of the public and democracy." Annals of the Association of American geographers 85 (1), 108-133.

Mitchell, D. (2001) "Postmodern geographical praxis? Postmodern impulse and the war against homeless people in the "postjustice" city." In Minca, C., ed. Postmodern geography: theory and praxis. Oxford: Blackwell, 57-92.

Mitchell, D. (2003) The right to the city. Social justice and the fight for public space. New York: The Guilford Press.

Mitchell, D., and Staeheli, L.A. (2006) "Clean and safe? Property redevelopment, public space and homelessness in downtown San Diego." In Low, S., and Smith, N., eds. The politics of public space. New York: Routledge, 143-175.

Pappalardo, M.L., and Marazzini, P. (2011) "Seduti sì, sdraiati no. Dalle panchine antibarbone di Verona uno sguardo sul diverso.” In Borghi, R., and Schmidt di Friedberg, M., eds. Lo spazio della differenza, Società Geografica Italiana Bulletin, Series 13, 5 (1),165-178.

Paté, G., and Argillet, S. (2005) "Bancs publics. Regard sociologique sur l'ordinaire des espaces urbains." Actes de la recherche en sciences sociales 159, 116-120.

Porcu, M. (2011) "Gated communities e chiusura degli spazi pubblici. Due casi di studio a confronto." Studi sulla questione criminale 3, 67-86 .

Sahlin, I. (2006) Urban definitions of places and behaviour. National Report for Sweden, Working Group 1, European Observatory on Homelessness, FEANTSA, Brussels. http://www.feantsa.org.

Sebaste, B. (2008) Panchine. Come uscire dal mondo senza uscirne. Bari: Laterza.

Sgroi, E. (1997) Mal di città. Milano: FrancoAngeli.

Snow, D.A., and Mulcahy M. (2001) "Space, politics and the survival strategies of the homeless." The American behavioral scientist 45 (1), 149-169.

Strassoldo, R. (1998) “Aspetti sociologici dell'urbanistica post-moderna.” In Mazzette, A., ed. Immagini di città, Milano: FrancoAngeli.

Tosi, A. (2007) “Homelessness and the control of public space. Criminalizing the poor?" European Journal of Homelessness 1, 225-236.

Wacquant, L. (2001) “The penalization of poverty and the rise of neoliberalism." European Journal on Criminal Policy and Research 9 (4), 401-412.

Waldron, J. (1991) "Homelessness and the issue of freedom." Ucla law review 39, 295-324.

Wasserman, J.A., and Clair, J.M. (2011) "Housing patterns of homeless people: the ecology of the street in the era of urban renewal." Journal of contemporary ethnography 40 (1), 71-10.

Wirth, L. (1938) “Urbanism as a way of life.” The American Journal of Sociology, 44 (1), 1-24.

Whyte, W.H. (2009) City: rediscovering the center. Philadelphia: University of Pennsylvania Press.

Williams, J. (2011) Homelessness as delinquency: how private interests enforce constructs of normalcy in public space. Paper presented to The Research Prizes in Practical Ethics for 
Undergraduates of the Poynter Center, Indiana University Bloomington.

www.poynter.indiana.edu.

\section{NOTES}

1. This article presents research based on qualitative methods. Our fieldwork concentrated on two phases. First of all, we made direct and systematic observations of public spaces within the inner city of Bologna. In the course of the research field process we adopted the typical techniques of visual sociology, creating and using images as tools for collecting relevant data for the purpose of the study. This photographic fieldwork allowed us to record, document and represent the investigated phenomenon in a visual form. In particular, we produced a visual documentation of the kinds of urban furniture which tend to keep undesirable individuals away from public space. From a collection of fifty photographs we have selected the ones shown in the present article as visual indicators of the exclusion of the homeless. We then analysed the various legislative interventions made by the municipal administrations of Bologna and of other Italian cities (Salerno, Verona, Treviso, Trieste, Padova, Belluno, Milan, Savona, Rome, Naples, Voghera, Vicenza, Novara, Gorizia, Monfalcone and Venezia), such as local by-laws and urban police regulations.

\section{ABSTRACTS}

This article addresses the relationship between homeless people and urban public space. The analysis, focusing on the Italian context and, in particular, on the city of Bologna, centres on urban policy strategies which tend to exclude the homeless from public spaces and to regulate their use of such spaces. Our considerations encompass three dimensions: the role of public space in the daily life of the homeless; the changes in public space following urban renewal processes; public space control mechanisms, in the form of urban design and local by-laws, which translate into a spatial exclusion of the homeless.

L'article porte sur le rapport des personnes sans domicile à l'espace urbain. Axée sur le contexte italien et notamment sur la ville de Bologna, l'analyse focalise l'attention sur les stratégies de politique urbaine visant à exclure ces sujets des espaces publics, ou à discipliner l'usage qu'ils font de ces mêmes espaces. Les réflexions des auteurs se développent sur trois axes: le premier concerne le rôle de l'espace public dans la vie quotidienne des sans domicile; le deuxième porte sur les changements des espaces publics provoqués par les processus de régénération urbaine; le dernier explore les mécanismes de contrôle de l'espace public qui, sous forme d'interventions urbanistiques ou d'arrêtés municipaux, produisent l'exclusion spatiale des sans domicile.

\section{INDEX}

Keywords: exclusion, homeless, public space, urban policies, urban renewal Mots-clés: espace public, exclusion, personnes sans domicile, politiques urbaines, régénération urbaine 


\section{AUTHORS}

\section{MAURIZIO BERGAMASCHI}

Dipartimento di Sociologia e Diritto dell'Economia, Università di Bologna MARCO CASTRIGNANÒ

Dipartimento di Sociologia e Diritto dell'Economia, Università di Bologna

\section{PIA DE RUBERTIS}

Dipartimento di Sociologia e Diritto dell'Economia, Università di Bologna 